Journal of Humanities, Social and Management Sciences (JHSMS)

eISSN: 2788-4791 (online)

https://doi.org/10.47264/idea.jhsms/2.2.1

Vol. 2, No. 2 (July-December 2021), 1-12

https://www.ideapublishers.org/index.php/jhsms

Research Article

\title{
A feministic critique of Jamil Ahmed's The Wandering Falcon
}

\author{
Zareena Qasim $^{1}$ | Adeela Iftikhar ${ }^{1}$ | Asifa Qasim*2
}

1. Department of English, Faculty of Arts and Humanities, Sargodha University, Sargodha, Pakistan.

2. Department of English Language and Translation Studies, College of Arabic and Social Studies, Qassim University, Saudi Arabia.

*Corresponding Author Emails: asifaqasim@gmail.com | a.awan@qu.edu.sa

Received: February 16, 2021

Published: August 29, 2021

\begin{abstract}
The study investigates the novel The Wandering Falcon (2011) by Jamil Ahmad in the milieu of feminist approach. It qualitatively explores the text for the representation of women: the treatment of women by men, and their position in the patriarchal society. The novel is analysed by employing De-Beauvoir's (1949) feministic philosophical approach in The Second Sex. This research explores the way power is exercised over women in the novel and the suppression of women by men plays as an instrument of transmission of customs and traditions. This research is to explore the novel from a feministic perspective to unveil the hidden realities in the novel regarding women to find out what sort of oppression is faced by women in the novel and to explore the general problems of women in the novel. It is found that in the context of the novel, women are treated unjustly by men. They are deprived of their rights and are taken as commodities in the patriarchal society. Women are stereotypically presented as having no identity, no freedom, and no voice of their own. Being treated as objects and things to be traded by men, women in the novel are found facing domestic violence, sexual objectification, and extra judicial killings.
\end{abstract}

Keywords: Pakistani fiction, feminism, feministic philosophical approach, women representation, patriarchy, power, suppression, violence.

\section{How to Cite:}

Qasim, Z., Iftikhar, A., \& Awan, A. Q. (2021). A feministic critique of Jamil Ahmed's The Wandering Falcon. Journal of Humanities, Social and Management Sciences (JHSMS), 2(2), 1-12. https://doi.org/10.47264/idea.jhsms/2.2.1

\section{Publisher's Note:}

IDEA PUBLISHERS (IDEA Journals Group) stands neutral with regard to jurisdictional claims in the published maps and institutional affiliations.

\section{Copyright:}

(C) 2021 The Author(s), published by IDEA PUBLISHERS (IDEA Journals Group)

This is an Open Access article published under the Creative Commons Attribution-NonCommercial 4.0 International License (http://creativecommons.org/licenses/by-nc/4.0/) 


\section{Introduction}

Literature is the reflection of life in a society. It unveils the truths of real world by creating a story and portraying it through male and female characters. The representation of male and female characters sets the readers' minds for gender disparities. This study is an exploration of the novel The Wandering Falcon (2011) through the feminist perspective. The text has been analysed using De-Beauvoir's (1949) feministic philosophical approach, as presented in The Second Sex, for the investigation of the position and treatment of women in the tribal areas of Pakistan. Feminism creates consciousness about male dominance and female inequality, oppression, and sexual objectification. Though feminist movements have raised much awareness for women's rights and social injustice, yet this reality could not be neglected in many cultures and different areas where women themselves are not even aware of their basic rights or they are made to accept the gender stereotypes constructed by the controlling forces of the culture, their oppressors ruling over them. Bertens (2017) views the representation of women in the literature as reinforcement of cultural and gender stereotypes depicting women as essentially dissatisfied, angels of sacrifice, cute but immoral and helpless, and so on.

The Wandering Falcon (2011) by Jamil Ahmad (1931-2014) is based on the lived experiences and observations made by the writer during his stay in the remote areas of Pakistan as an administrator. The whole novel is a collection of nine stories that could be enjoyed individually but these are also connected with the central character named Tor Baz (Black Falcon, p.68) who lives like a wandering falcon as a survivor fighting for his identity. The novel reflects the social, cultural, economic, religious, and domestic code of conduct of the people belonging to different tribes settled in FATA, federally administered territory of tribal areas, and Baluchistan. Ahmad depicts the miserable condition of marginalized tribal women in the pretext of harsh tribal culture where violence against the women is an outcome of traditionally held gender beliefs about the subordination and inferiority of women. Focusing on the feministic philosophy to understand the representation and role of women, the study reveals feministic themes like discrimination, oppression, patriarchy, and gender inequality in the text.

The main objective of the present research is to explore the novel The Wandering Falcon from a feministic perspective to unveil the hidden realities in the novel regarding women to find out what sort of oppression is faced by women in the novel and to explore the general problems of women in the novel. The study is guided by the following research questions: a) What are the patterns of gender and power relations in the selected text? b) How are the existing power structures exercised in the novel?

\section{Literature review}

The unjust treatment of women is widely discussed in the history. Mill (1869) condemned the treatment of women as sex-slaves and domestic servants, the vicious attitude of the society towards women, and the oppression in marriage for women. Mill stressed that all the thoughts leading to women subordination must be eliminated and men should be morally trained to deal women as their equals. Stone (2004) states that genealogical view, "constitutes women as a group whose history, and consequent social positions, can be identified as distinctively oppressive" (p. 151).

Talpade (1991) argued that woman of the third world should not be judged under the western 
feminism being an established norm, but under the particular social circumstances in which she is living and the problems of third world women must be evaluated in accordance with their social context. Mumtaz and Shaheed (1987) discussed that a considerable difference also exists among women with regards to different geographical areas of country. They state: "to talk of Pakistani women is in fact to talk of groups of women, of clusters of similarity in a disparate reality" (p.21).

Ahmed (2009) investigated the portrayal of female characters in Pakistani English fiction and observed that women of different age and social background are portrayed in the Pakistani fiction along with their problems (social, psychological and behavioural) which they faced in the patriarchal society in the form of social taboos. The author also argued that Pakistani women from upper strata are presented as role models in Pakistani fiction struggling for empowerment and competing with the patriarchal society.

The Wandering Falcon (2011) by Jamil Ahmad has been investigated from different perspectives but the feministic perspective remains under explored. Imran and Gull (2017) studied the novel the Wandering Falcon in relation to Bapsi Sidhwa's the Pakistani Bride to explore the culture of lawless killing in the name of honour. Discussing different attitudes towards people involved in these extra judicial killings, Imran and Gull condemned the killing of men and women above the law in Pakistani tribal cultures.

Ahmad et al. (2019) investigated the theme of warrior traits stylistically and linguistically in The Wandering Falcon and dig out the culture and traditions of the people of FATA through the stylistic analysis of the text. Sadaf (2018) explored the themes of human dignity and war in terror in two post 9/11 novels, The Wandering Falcon and The Burnt Shadows, written by Pakistani writers, and stated that "While Shamsie stresses the need for a broader historical contextualization of recent events that have caused a global divide, Ahmad's work is an attempt to humanize tribal populations of Pakistan perceived as the 'enemy' in the war against terrorism" (p. 115). Khanal (2016) discussed the identity crisis faced by the central character Tor Baz, who becomes a culturally hybrid person due to the circumstances of his life and adopted different cultures in course of his life.

Nazir (2020) worked on the Pakistani post-colonial fiction brand by analysing three novels, i.e. The Wandering Falcon, The Reluctant Fundamentalist and The Golden Legend. He explored the reception of these novels by the people of South Asia and the West by analysing the reviews on these novels. He concluded that the authors have focused on the international market and developed the brand accordingly for the financial gains and the literary acknowledgment, and due of these reasons; they often diverge from the actual representation of people in their fictional works.

The novel has been analysed and interpreted through different perspectives, but feminist dimension of the text has not been explored in any previous study on the novel. Therefore, the present study aims to investigate the text from a feminist perspective through De Beauvoir's (1949) feministic philosophical approach. The analysis involves extensive textual interpretation of the text to encroach the tribal culture and the way it clashes with mainstream progressive culture. The harshness of the tribal culture and the aggressive attitude of community is manifested in the hardships faced by tribal women in the form of violence, sexual objectification, and honour killing. 


\section{Theoretical framework}

The theoretical framework chosen for the investigation of the novel under study is that of a French feminist De Beauvoir's philosophical approach in The Second Sex (1949), which is a prominent work in feministic philosophies. De Beauvoir discussed the treatment of women historically through discrimination, inequality and the otherness associated with women. According to her, women's understanding of their gender roles is shaped by the gender perceptions of the society and women tend to modify themselves to adopt socially acceptable submissive behaviours. The data is analysed manually, and textual lines loaded with women's representation are extracted and analysed to answer the research questions. For this study, the text has been analysed for gender relations and power structures in the light of De Beauvoir's feministic philosophical approach. The following points from De Beauvoir's theorization of female oppression as discussed in The Second Sex, have been used as guiding points:

\subsection{Women as negative}

The primary question, De Beauvoir raises in The Second Sex is "What is a woman?" (p. 5) to which she responds that:

"If I want to define myself, I first have to say, "I am a woman"; all other assertions will arise from this basic truth. ... for man represents both the positive and the neutral, as is indicated by the common use of man to designate human beings in general; whereas woman represents only the negative...A man is in the right in being a man; it is the woman who is in the wrong" (p. 5).

\subsection{Women as oppressed}

She describes the One/Other relationship in the first few pages of The Second Sex as inescapable and fundamental feature of the human circumstances and the main idea is that keeping in mind the state of affairs, there is very little hope for women. "Thus, humanity is male, and man defines woman not in herself but as relative to him; she is not regarded as an autonomous being... She cannot think of herself without man. (P.6)"

\subsection{Objectification of women}

"And she is simply what man decrees; thus, she is called 'the sex', by which is meant that she appears essentially to male as a sexual being. For him she is sex - absolute sex, no less" (p. 6).

\subsection{Women as inessential}

"She is defined and differentiated with reference to man and not he with reference to her; she is the incidental, the inessential as opposed to the essential. He is the Subject; he is the Absolute - she is the other" (P. 6).

\subsection{Women as inferior}

De-Beauvoir tries to trace the origin of inequality and submissiveness of women "woman has always been man's dependent, if not his slave; the two sexes have never shared the world in 
equality. And even today woman is heavily handicapped... Yes, women on the whole are today inferior to men" (p. 11)

\subsection{Women's acceptance of their submissive position}

Beauvoir argues that the woman "knows that when people look at her, they do not distinguish her from her appearance: she is judged, respected, or desired in relation to how she looks" (TSS, p. 24). She further argues that for "a woman to accomplish her femininity, she is required to be object and prey..." (TSS, p. 723).

\subsection{Gender roles}

She asserts that "In today's work, without even mentioning the women who work on the land, most working women do not escape the traditional feminine world; neither the society nor their husbands give them the help needed to become, in the concrete terms, the equals of men" (TSS, p. 722).

\section{Data Analysis and discussion}

Analysis of the text proved to be an interesting job, as it was found replete with the evidence matching with the philosophical approach of De Beauvoir towards feminism. The novel begins with the story of a woman and man (lovers) who eloped together and met the subedar (junior military officer) and his soldiers asking them for shelter and food. The woman is Gul Bibi. When her face is unveiled most of the soldiers turned their faces, to honour the tradition of pardah (secrecy of women). However, those who saw her, observed that "she was hardly more than a child" (p. 6). Though they were lovers, still the authority and dominance of the man over the woman is clearly noticeable: "The man motioned for the woman to stop, and walked up, by himself, to the subedar commanding the fort" (p. 6). Even though it could be stated that it is custom of the tribal people to keep their women away from other men not allowing them to see other men, but it could also be inferred that these traditions and customs are established and practiced by man in order to keep full authority and hold on a woman, and also to keep her as a puppet so that he may enjoy full authority over her body and soul.

When the man is given water by the Subedar, he rushes back to the woman (Gul Bibi) who is in terrible state out of thirst and fatigue, the soldier expressed much disgust upon his action of having her in his lap though it was done for providing her with water, and the author has commented that he was shameless. The author has also compared the woman with an animal, which also expresses the general attitude of male-dominated patriarchal society towards women, "After the man had cleansed her face, the Baluch cupped his right hand and splashed driblets of water onto her lips. As she sensed water, she started sucking his hand and fingers like a small animal" (Ahmad, 2011, p. 6).

Gul Bibi works in her home and beautifies everything of her little world as much as she can (p.7). She has made the brooms for cleaning and baskets which for the soldiers. The author has typically drawn the picture that women are expected to do the house chores. After doing all the work, Gul Bibi feels proud of herself as if she has achieved a goal and waits for her lover to see her work and to appreciate her. It shows that women are in thirst of approval and appreciation of their men, to whom they always remain subordinates. When Gul Bibi's lover 
came home after performing his duties for the soldiers, instead of appreciating her work, he asked her to break the towers built by her, "My love, take away the towers, there is something about them I do not like...she rushed frantically toward them and crumbled them back into clay" (Ahmad, 2011, p. 7). It has been explained later in the text that the tribal people entombed the bodies of the sinners in the similar shape of towers, but the noticeable thing is that the man cared about his own thoughts and not about the feelings of Gul Bibi, his love who has worked hard to build the towers. Ahmad (2011) sketches the mental state of Gul Bibi and her lover through their discussion about the future of their son:

"She thought for a while. Let him be a camel herder, handsome and gentle as his father," the woman murmured.

"And fall in love with the sardar's daughter, his master's wife," the man countered. "And carry her away," continued the woman (p. 7)."

In the text quoted above, the choice of vocabulary reveals the difference in the status of both Gul Bibi and her lover and the lack of identity of the woman. Her lover refers to her as the daughter of Sardar (leader of the tribe) and wife of master and not by her name, which shows that she has no independent identity and is bound to be referred as the daughter or the wife of a man. On the other hand, Gul Bibi referred to her lover as a 'handsome and gentle man'.

When the child became five years old, they were approached by a Siahpad (through a representative of their tribe named Siahpad) being fearful by his secret visit, they left the place. However, they found no escape and were soon surrounded by the Siahpad (their tribe) led by Gul Bibi's father and husband. The couple (lovers) had decided earlier what to do in such situation. Accordingly, the man shoots the woman to let her escape from the brutal death prescribed by their tribal traditions and he was stoned to death by the group of Siahpads who left their son alive after argument. Entombing the dead bodies of Gul Bibi and her lover, the Siahpads created a symbol of Siahpad's revenge. The lovers became the victims of honor killing: "They used mud and water to plaster the towers so that their work might endure and provide testimony, to all who cared, about the way in which the Siahpad avenged insults" (Ahmad, 2011, p. 8). After getting married there is no road back for a woman and running away from husband even if he is impotent. This is a crime for which she is punished by killing.

He glanced at the sprawled body of his daughter and looked at her lover. "Who is the boy?" he asked. His voice was cold and without emotion. The voice of a stranger. (Ahmad, 2011, p. 8). The author has titled the first section of the novel as 'The Sin of the Mother', which shows the general attitude of the society and the discrimination on the basis of gender. Though, both Gul Bibi and the man eloped together, and both were sinners in the eyes of the community and religion for the illegitimate relation they had, only the woman who later becomes 'mother' is referred to be sinful.

There are different examples of women in the novel who are treated as commodities and are sold by men having power over them. The women have accepted it as their destiny. In the third chapter, The Death of Camels, Torak Khan told Sardar Karim Khan Kharot about the unpaid price of his mother's marriage. It shows that the society is patriarchal where not only the father and the husband but also the son of a woman has the ownership of her, and she willingly becomes subordinate to him. Women are not treated as equals to men, but they are being treated as a property of men who give them away in marriages and in turn take money. This is again 
the custom of the tribal people but that very custom has also highlighted the otherness of the women in the patriarchal society. She is being traded by her own blood relations, father, brother or son, who have the privilege to own her, as if she is an animal for whom they are making deals in the name of bride price.

The devil married my mother after my father's death and did not pay any bride price. As the eldest son, the money is due to me, and the man refuses to pay it. I have to get it out of him. My mother agrees with me (Ahmad, 2011, p. 15). In the chapter "A Kidnapping", there is another reference of bride price supposed to be paid by Sarmast Khan, "This time, he was in need of money for himself. The father of the girl betrothed to him had been pressing for payment of the balance of the bride price" (Ahmad, 2011, p. 24). It is also revealed that a husband has complete authority over his wife as well as her daughter, and it is up to him to let the woman involve in his matters or not, as Amir Khan in the chapter "The Guide" sold his daughter to Hamesh Gul without letting his wife know that to whom her daughter is going to be married. Then the husband has the privilege of controlling his wife who does not have any freedom, not even the freedom to meet her parents according to her own wish. The cultural forces have played their role to make them habitual to those marginalizing practices.

"Is anybody home in Amir Khan's house?"...

"Who is it, wanting to know?" a woman's voice shouted back.

"It is I, Hamesh Gul, Amir Khan's son-in-law."

"Which daughter of mine have you married?" the disembodied voice called back skeptically.

"The one after the eldest, I have brought two guests."

...As we entered, she caught Hamesh Gul by his sleeve.

"How is my daughter?" she asked.

"She is well," he replied. "I will ask her to look you up." (Ahmad, 2011, p. 29)

The narrator commented here "... Hamesh Gul had never visited his in-laws, nor had the old woman seen her daughter after the marriage. That was now more than twenty years ago" (Ahmad, 2011, p. 29). Though, it is often said that the bride price is not the sale of the woman, but some help to the parents of the girl to be married, but it still is a sale in disguise as the girl is completely ruled upon by the man who pays for her and she pays the penalty throughout life. The author also introduced the life of the Powindah (a nomad tribe) people, who are not settled in any specific geographical areas but keep on switching their residence between Pakistan and Afghanistan with the change of season. In this section the author mentioned the duties performed by the male and female members of the tribe. The men were busy unhitching the panniers from the animals and bringing their loads to the tents, mostly carpets, dried fruit, and nuts, which they carried with them to sell in the cities. The women, too, were busy, cooking and milking the she-camels and sheep, or suckling their babies (Ahmad, 2011, p. 14).

The men are seen here doing some work instead of leaving all the matters upon women while their female counter parts are responsible for providing the meals and also the tasks regarding their animals. These women of Powindah people are different from the other women presented in the novel, in a sense that they are given the freedom of speech to some extent. Among these Powindah people, Gul Jana who is the wife of Dawa Khan is portrayed as a courageous and bold character in her remarks and decisions as compared to the other women in the novel. Though women usually not reply to any man in that specific tribal culture, she replies to Sardar 
Karim Kharot from behind the pardah. Gul Jana also makes a bold remark to a soldier who gazes at her. She feels safe by threatening him of her husband's power as she herself felt harassed and powerless.

"You, there!" She put a hand to the side of her mouth. "You, there, who has been staring at me for a long time. Do you not know that you are smaller than my husband's organ? (Ahmad, 2011, p. 16).

The author describes the nature of women of the plains through the mouthpiece of another character in the novel whose name is Ghuncha Gul for whom the behaviour of the soldier starring at Gul Jana is acceptable. She also compares the women of her tribe with those of plains and concludes that the women of plains are less attractive and lack femininity. The words quoted below express the judgmental view of the patriarchal society where men want the women to be submissive.

The women of the plains kept to themselves and were severe and serious in their demeanour. He decided not to commiserate with the soldier. That gesture might hurt him all the more, and, in any case, it was better for the boy to suffer the jolt of the ribaldry and boisterous humour of the Powindah women before he made any serious mistakes (Ahmad, 2011, p. 16). Gul Jana's courage is also depicted by the decision that she took when they were not allowed to go farther as restrictions were imposed upon them by the government.

The women had been listening to this exchange between their men and the soldiers. Gul Jana called out to her husband, Dawa Khan, I am going forward. The camels must not die. I am going with a Koran on my head (Ahmad, 2011, p. 18). She is shot dead along with her husband. Her freedom of speech and the ability to take decision is supported by Dawa Khan who allowed her to do so, and we see that she is not forced to keep silent or expresses her opinion while living in pardah.

The section named as A Kidnapping throws light on the social, cultural, economic, and domestic patterns of two rival tribes Mahsud and Wazir settled in Waziristan. The warrior traits of the men are evident as the author described women involved in taking care of lands and fetching water while the men were engaged in violent acts: "Every few months, the hate and tensions explode into violence and some men die, never the women, who continue caring for the land and fetching water from the river" (p. 24). The author again referred to women fetching water for their men and the restrictions imposed upon them in the following words in the chapter, The Guide: their behaviour while passing across the strangers could be compared to the Powindah women, who are allowed to speak before strangers and are also reported to laugh loud in the presence of soldiers:

"A few girls walked past with water pitchers on their heads to fetch water from some spring, perhaps miles away. They would make at least three trips during the day to get water for their men folk, and yet find it within themselves to make another trip to refill the wayside casks that provided water for travellers. They were talking brightly among themselves, but their chatter fell silent as they approached the party of strangers. In this land where imputation of immorality meant certain death, both men and women were careful" (p. 29). 
The author also mentioned the girls, even little girls loaded with firewood to be sold at their desired places and the girls and boys herding flocks of animals. Harassment to women is also mentioned in the novel in the chapter, The Guide: "It was together that we made our first bold remarks at some girls and then hid together the rest of the day, worrying whether they would tell their fathers, who would come after us" (Ahmad, 2011, p. 31).

There is mention of a girl named as Sherakai being sold by her father in the chapter A Pound of Opium: "He had sold her to somebody before he left, for a pound of opium and a hundred rupees and lost the right upon his daughter Sherakai-the one that by rights he should have forgotten" (p. 34). Sherakai was only eight years when she was sold for the first time, by her own father. In the patriarchal setup of that tribal area, the author portrayed that the girls are treated as sexual objects being sold and used by men. The prince also bought Sherakai as a sexual object. Her mother tried hard to get her daughter back, but the prince was determined to have sex with the girl, and he also attempted to do so:

"It had taken her mother another year to save the money to buy her back, and still the prince had refused to let her go. She could even now feel the terror when, at her mother's pleading to spare her child, her owner had laughed coarsely and said, "A child? She is a Sherakai. I assure you if she can accept a small finger, she will find no difficulty in accepting a man's organ" (Ahmad, 2011, p. 35).

Somehow, her mother managed to get her back and after three years, arranged her marriage, she was living a satisfied life until she was kidnapped in a raid as told later in the last chapter of the novel, "...had been kidnapped in a raid but had escaped and returned to find that her husband had taken a younger wife, who had borne him a son" (p. 41). She reached her home after running from the kidnappers but after getting beaten and ridiculed by her mother-in-law and the second wife of her husband for not being able to produce a son, ran away from there. This is again brutal attitude of society towards women that they are mistreated by men as well as the women for producing daughters and the society imposed much pressure upon women to give birth to a boy as it is mandatory for a woman to be the mother of a boy to gain respect in the society. It is also seen that in case of two or more marriages, the woman having a son is more privileged than the woman having daughters as depicted through the example of Sherakai. She is tortured by her mother-in-law and the second wife of her husband but the role of the husband as protector is missing here as she is not saved from the brutality by him.

There is another example of a girl being sold in the next chapter, The Betrothal of Shah Zarina, in which Fateh Mohammad, a Gujjar (a Punjabi family name) has sold his daughter Shah Zarina: "This young man had asked for the hand of Shah Zarina. The negotiation about the bride price had been successful, and the marriage would be taking place after one month" (p.37). The author has used the word 'negotiation' (p.37) which implies the irony of the fact that the bride price is paid before the marriage of the girl. Shah Zarina is the girl who faces the unjust treatment of her husband who gives more importance to his bear than his wife as she has to leave her room for the bear's return. "She could not understand why the bear had to have a room and they could not. Once she asked her husband. He looked at her coldly and said, "I can get another wife but not another bear" (p. 38). Shah Zarina out of jealously tried to hurt the bear and was hit brutally by her husband who used to beat her regularly: 
"From then on, Shah Zarina's life underwent another change for the worse. Her husband made sure that Shah Zarina would not get another chance to hurt the animal. This he did in a coldly logical way by insisting that she would live a life no more comfortable than that of the bear. If the bear ate his food so did Shah Zarina. If it chose to go hungry so, would she. If the bear stayed awake during the night, Shah Zarina could not join her husband in the only quilt they had. In the morning, along with the bear, Shah Zarina would get her day's beating. After a few months of this, Shah Zarina broke down and ran away from her husband" (p. 38).

After some time of her return Shah Zarina's parents discussed about the circumstances that they have no right upon her, and they have to pay back the bride price in case they want to take their daughter back, as stated by Ahmad (2011):

"Her husband is bound to come by any day. He will demand that she be handed over to him. That is his right. If we refuse, he will ask for the return of the bride price," added her father.

"But we have already spent the money!" her stepmother whined.

"She has created a terrible problem for us all" (p. 38)

She is a girl who is crushed by the customs and traditions and not supported even by her father. Her emotions and mental health meant nothing to her parents who are only worried about the price that is to be returned if she stayed there. Shah Zarina listened to the conversation of her parents and having no other option for herself; she left the house at night out of helplessness and deep sorrow. The last chapter, 'The Sale completed' depicts the situation of objectification of the women. There is a place where women are bought and sold on every Thursday:

"Another two faces to add to the multitude in his memory, growing with the passage of each Thursday. Women, some little more than infants, some already on the threshold between middle and old age; some who laughed at their fate and others who never stopped crying. Some who appeared once and then vanished completely. Others came again and again, sold sometimes to one man and then to another. There were those who had run away from their husbands or their fathers and those who were running away from life" (p. 41).

It is revealed that Shah Zarina and Sherakai (the daughter of Sher Beg) are taken to be sold by a stranger Afzal Khan whom they met on their way. They are added to the multitude in the memory of the tea boy who witnessed those sales of women every Thursday. The specific place for women's trade shows that in tribal areas, women are left with no choice other than to escape from their husbands or fathers. It further shows that they cannot live in that community at their own. They have to remain under the ownership of a man. If their problems were solved and they were given due importance, they would never leave their houses. The irony of the fact is that they are treated as objects, and after running from their houses they are sold by strangers to other men. They suffer from identity crisis and are meant to be sold only, though this sale does not give them any benefit except becoming sexual slaves of other men. Sherakai is sold to two traders who would share her, and Shah Zarina is sold to a young man for three thousand rupees. "I have sold you for marriage. This young man is going to marry you. May God keep 
you happy." (Ahmad, 2011, p. 42), said Afzal Khan to which Shah Zarina replied, "I thank you," she said simply. "I shall always pray for you" (Ahmad, 2011, p. 42).

The women represented in the novel are crushed under the weight of patriarchal traditions and customs; they have no opportunity to live an independent life but are bound to live as a property of some or other man. It would not be incorrect to state that they have no rights on human grounds as Shah Zarina is not supported by her parents or by the society in which she lived. Similarly, Sherakai did not find any option other than to be sold by a stranger. It is portrayed by the author that the females of all ages are considered as sexual objects and are bought and sold without any difference.

To sum up the discussion, it could be stated that the customs and traditions presented in the novel are set to marginalize and target women, and to rule upon them through so called rules of the tribal area, as Shamsie (2005) states "As lawlessness spread, ancient tribal customs were confused with religion, the killing of women in the name of honour increased, and a parallel system of justice, village Jirga, ensured further victimization" (p. xix).

\section{Conclusion}

Studying the novel, The Wandering Falcon (2011), from feministic lens reveals that women are treated as commodities, having no voice and choice of their own. The first chapter of the novel introduces the plight of a woman being unable to get rid of her impotent husband as the law did not allow her, and the terror that she faced after running with a man in the form of honour killing. The tribal people follow their own customs and traditions, and women are the voiceless victims of these traditions. Women are sold in the name of marriage by their fathers, sons, and even strangers. Girls as Sherakai may be sold at the age of eight. Amir Khan sold his daughter to Hamesh Gul, who never allowed his daughter to meet her family and mother in the twenty years after her sale.

The women presented in the novel are seen doing household work like fetching water for their menfolk and taking care of their children, but in spite of all these efforts they are not welltreated by men. Shah Zarina is an example of women, facing domestic violence, whose husband gave preference to his bear over his wife and used to beat her regularly. Women are not allowed to talk to strangers, it is only Gul Jana who is presented as a courageous woman who attempted to raise her voice and took a decision in the patriarchal society; but it is also noteworthy that Gul Jana's freedom is granted by her husband. There is also a woman named as Sherakai, who loved her husband but was forced by her mother-in-law and the second wife of her husband to leave the house, as they beat her in front of her daughters and taunted her on her inability to produce a boy. Thus, she is an example of the women harmed by other women for lack of support from their husbands against that brutal behaviour of their families.

The novel presented the feeble tribal women as passive, powerless, deprived of their rights, treated as commodities, having no voice, identity, and freedom of their own, facing discrimination, injustice and domestic violence in a predominantly patriarchal society. Being treated as objects and commodities to be sold and ruled upon by men who have bought them, women in the novel are facing inequality and extra judicial killings. The power structures depicted in the society showed women at the bottom of hierarchy being subordinated and crushed by men who have power over them. The novel can be further analysed from 
psychological, sociological, political, or behavioural dimensions to provide readers deeper insights into different cultural phenomena and the role of different characters in multiple dimensions. An individual psychological approach to the analysis the Wandering Falcon can extend the scope of the present study by focusing on the struggle of different characters to achieve their goals. Moreover, the novel can be compared with other Pakistani novels for the reflection of tribal society, patriarchy, and gender representation.

\section{References}

Ahmad, G., Tahir, A., \& Asif, M. (2019). Warrior traits of Pakistani tribal community: A stylistic analysis of lexical and syntactic choices in The Wandering Falcon. International Research Journal of Arts \& Humanities (IRJAH), 47(47), 61-72 https://sujo-old.usindh.edu.pk/index.php/IRJAH/article/view/5124

Ahmad, J. (2011). The Wandering Falcon. Penguin Group.

Ahmed, Z. (2009). Pakistani feminist fiction and the empowerment of women. Pakistaniaat: A Journal of Pakistan Studies, 1(2), 90-102. http://www.pakistaniaat.org/ doltala/index.php/pak/article/view/24

Bertens, H. (2017). Poststructuralism continued: Foucault, Lacan, French feminism, and postmodernism. In Literary Theory: The Basics (pp. 131-157). Routledge.

De-Beauvoir, S. ([1949] 2010). The Second Sex (Trans. Constance Borde and Sheila Malovany-Chevallier).

De Beauvoir, S. (1949). The Second Sex (Trans). Vintage Books.

Imran, M., \& Gull, A. (2017). Victims of honour Killing in Bapsi Sidhwa's the Pakistani Bride and Jamil Ahmed's the Wandering Falcon. European Journal of English Language and Literature Studies, 5(3), 22-27. https://www.eajournals.org/wpcontent/uploads/Victims-of-Honor-Killing-in-Bapsi-Sidhwa's-The-Pakistani-Brideand-Jamil-Ahmed's-The-Wandering-Falcon.pdf

Khanal, P. R. (2016). Rootless identity in Jamil Ahmad's The Wandering Falcom. Unpublished Doctoral Dissertation, Central Department of English Kirtipur, Kathmandu.

Mill, J. S. (1869). The subjection of women. Routledge

Mumtaz, K., \& Shaheed, F. (1987). Women of Pakistan: Two steps forward, one step back. Zed Books.

Nazir, B. (2020). Brand Pakistan: A reception-oriented study of Pakistani Anglophone Fiction. Unpublished Doctoral Dissertation. Massey University, New Zealand.

Sadaf, S. (2018). Human dignity, the war on terror and post-9/11 Pakistani fiction. European Journal of English Studies, 22(2), 115-127. https://doi.org/10.1080/13825577.2018.1478255

Shamsie, M. (2005). And the world changed: Contemporary stories by Pakistani Women. Women Unlimited, xi-xx.

Stone, A. (2004). Essentialism and anti-essentialism in feminist philosophy. Journal of Moral Philosophy, 1(2), 135-153. https://brill.com/view/journals/jmp/1/2/articlep135_2.xml

Talpade, M. C. (1991). Under Western eyes: Feminist scholarship and colonial discourse. In Mohanty, C. T., Russo A., \& Torres, L. (eds), Third world women and the politics of feminism (pp. 51-80). Bloomington \& Indianapolis: Indiana University. 